\title{
Darkwinged Fungus Gnats, Bradysia spp. (Insecta: Diptera: Sciaridae) ${ }^{1}$
}

\author{
F. W. Mead and T. R. Fasulo ${ }^{2}$ \\ Introduction
}

Most species of darkwinged fungus gnats (Sciaridae) feed on fungi and decaying organic matter and are not considered economic problems. A few species, however, attack healthy tissue of such economic plants as potatoes, wheat, red clover, alfalfa, cultivated mushrooms, pine seedlings, and various ornamentals, including tulip bulbs, ferns, begonias, coleus, geraniums, cacti, young orchids, areca palm, and dracaenas. Sciarids are a problem in Florida greenhouses, mostly concerning injury to plants, but also large numbers of flying gnats being an occasional nuisance to workers.

Some growers have had difficulty achieving adequate control of these fungus gnats, and more information is needed on effective insecticides, dosage rates, methods of application, and possible phytotoxicity.

\section{Synonymy}

Sciaridae was formerly a subfamily in Mycetophilidae, and, for a short time, sciarids were called lycoriids (Lycoriidae). Many of the species formerly in genera Sciara and Neosciara are now in the genus Bradysia.

\section{Distribution}

Steffan (1966) reported that Bradysia was represented by 65 species in North America and is the largest genus in the family in North America and Europe. It also is found on all other continents and on most of the major islands. In the USA, the species seem to be mostly in the northern and western states. Examples of Bradysia have been collected from all regions in Florida, but very few have been determined to species. Based upon the available literature, R.J. Gagne, USDA Systematic Entomology Lab, Washington, DC, identified sciarids from greenhouses in the Apopka area, Orange County, as Bradysia coprophila (Lintner) and Bradydia impatiens (Johannsen). Also, he has identified $B$.

1. This document is EENY-215 (originally published as DPI Entomology Circular No. 186), one of a series of Featured Creatures from the Entomology and Nematology Department, Florida Cooperative Extension Service, Institute of Food and Agricultural Sciences, University of Florida. Published: July 2001. This document is also available on Featured Creatures Website at http://creatures.ifas.ufl.edu. Please visit the EDIS Website at http://edis.ifas.ufl.edu. Additional information on these organisms, including many color photographs, is available at the Entomology and Nematology Department Website at http://entnemdept.ifas.ufl.edu/.

2. F. W. Mead, Florida Department of Agriculture and Consumer Services, Division of Plant Industry, and T. R. Fasulo, Department of Entomology and Nematology, University of Florida, Gainesville, FL.

The Institute of Food and Agricultural Sciences (IFAS) is an Equal Employment Opportunity - Affirmative Action Employer authorized to provide research, educational information and other services only to individuals and institutions that function without regard to race, creed, color, religion, age, disability, sex, sexual orientation, marital status, national origin, political opinions or affiliations. For information on obtaining other extension publications, contact your county Cooperative Extension Service office. Florida Cooperative Extension Service / Institute of Food and Agricultural Sciences / University of Florida / Larry R. Arrington, Interim Dean 
coprophila from Punta Gorda, Charlotte County, and Gainesville, Alachua County.

\section{Description}

Larvae: The larvae are white, slender, legless, with a black head and smooth semi-transparent skin revealing digestive tract contents, length when fully grown $1 / 4$ inch $(6 \mathrm{~mm})$. There is nothing else similar in the greenhouse.

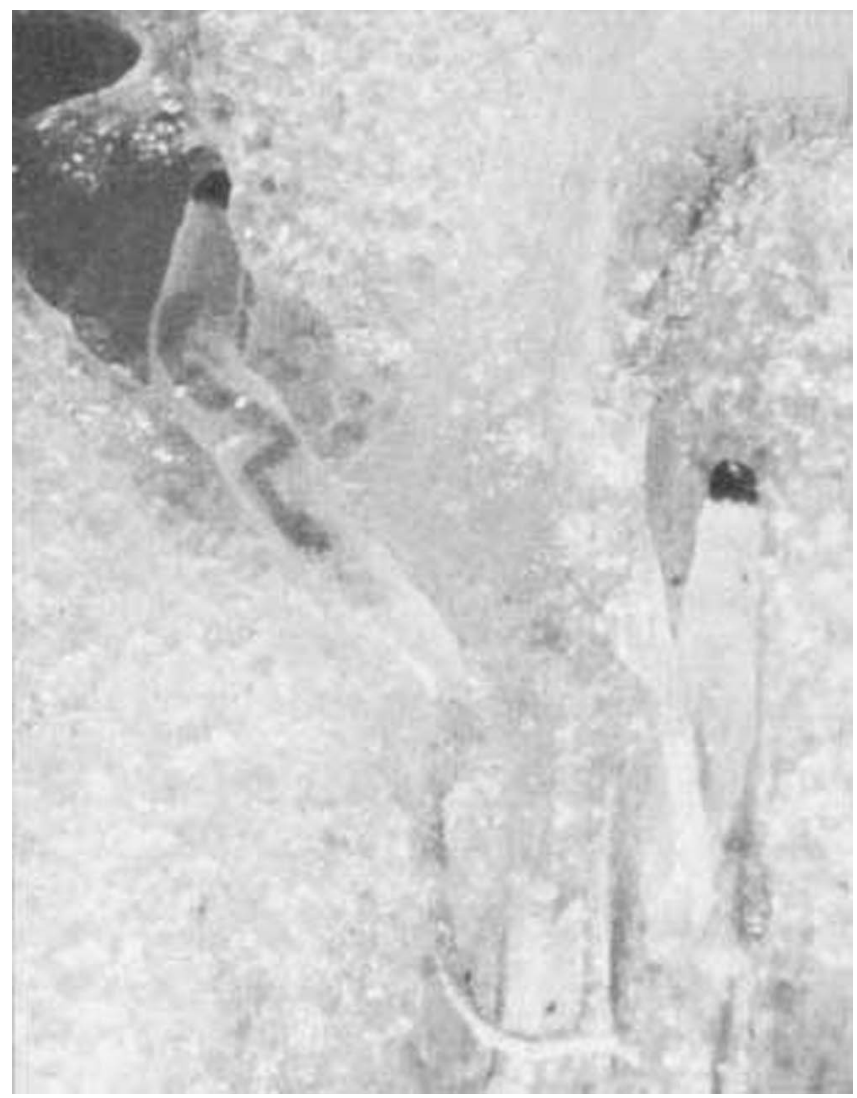

Figure 1. Darkwinged fungus gnat, Bradysia coprophila (Linter), larvae feeding on cactus tissues. Credits: Division of Plant Industry

Adults: The adults are small, up to $1 / 8$ inch (3 $\mathrm{mm}$ ) delicate flies, dark brown body, dusky wings, small head, rounded, moderately prominent eyes that meet above the bases of the thread-like antennae, legs and wings comparatively long. Fungus gnat adults are about $1 / 8$ inch long, spindly flies with long legs and long, thread-like antennae. They look more like tiny mosquitoes than common flies.

Valley (1975) described behavior of adult sciarids near infested potted plants, soil, etc. He wrote that when disturbed, the gnats run rapidly or take

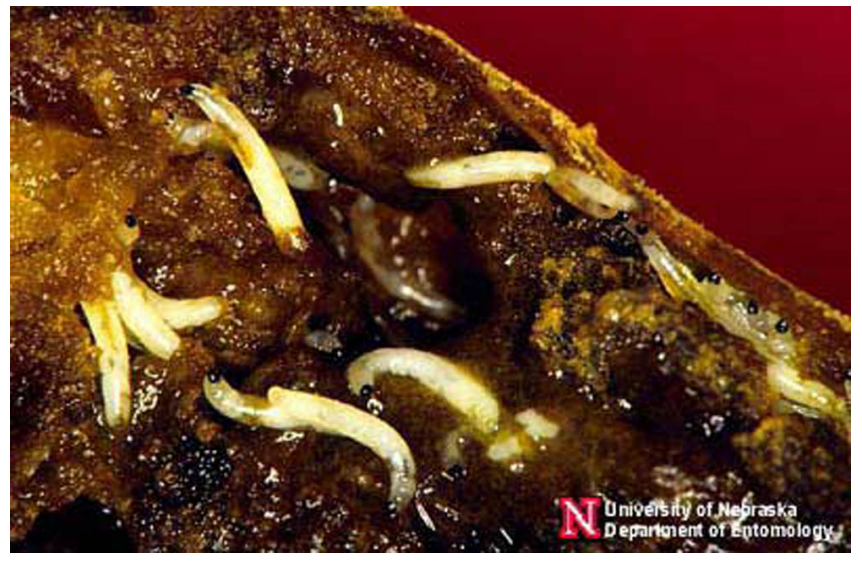

Figure 2. Darkwinged fungus gnat larvae feeding in rotten potato. Credits: Jim Kalisch, University of Nebraska Lincoln

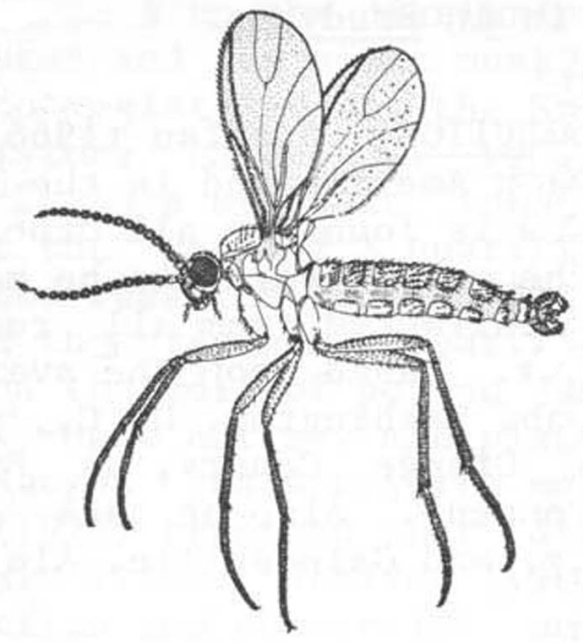

Figure 3. Adult darkwinged fungus gnat, Bradysia coprophila (Linter). Credits: Steffen (1966) slightly modified

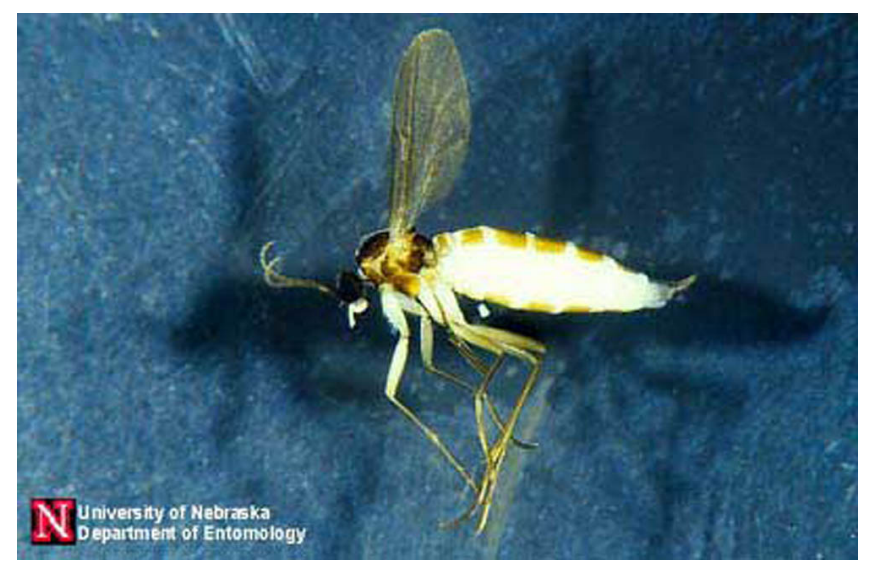

Figure 4. Adult darkwinged fungus gnat. Credits: Jim Kalisch, University of Nebraska - Lincoln

flight, which usually consists of short darting or hovering movements over a small area. 


\section{Identification}

In North America, the key to sciarid genera by Shaw (1953) has been superseded by Steffan (1966). Identification at the species level is difficult, based primarily upon males which must be cleared with $\mathrm{NaOH}$ or $\mathrm{KOH}$ and mounted on slides, a somewhat delicate procedure. The primary references are Johannsen (1912) and Pettey (1918), but as Steffan (1966) pointed out, many of the older descriptions are inadequate by current standards, and type material must be seen to insure accuracy of determinations.

\section{Bionomics}

The bionomics of Bradysia impatiens are well treated in the two papers by Wilkinson and Daugherty (1970a,b), which were inspired by observations of Daugherty in 1965 that larvae of B. impatiens attacked roots of soybean seedlings grown under aseptic conditions in a laboratory. They (1970a) reported that at $75^{\circ} \mathrm{F}\left(24^{\circ} \mathrm{C}\right)$ in the laboratory the average fecundity of a female was 75 eggs, and length of life cycle about 27 days; however, when temperatures were fluctuated to produce optimum development, the life cycle was about 19 days. Kennedy (1974) reported that the strain of $B$. impatiens he worked with had greater fecundity and shorter mean developmental time (15.6 days at $\left.77^{\circ} \mathrm{F}\right)\left(25^{\circ} \mathrm{C}\right)$ than the population used by Wilkinson and Daugherty.

Kennedy (1974) reported on the significance of fungi in survival and development of $B$. impatiens, a fungus gnat found commonly in greenhouses of New York State. He reported that larvae of this species frequently feed on the root and stem tissue of many greenhouse plants. His experiments suggested that fungi provide an essential nutrient source for the larvae of $B$. impatiens, and that if fungi are in low supply in the immediate vicinity of a living plant, there is a tendency for the larvae to use the plant as an alternate food source.

Hungerford (1916) reported the life cycle of Sciara (=Bradysia) coprophila was 24 to 32 days from egg-laying to egg-laying adult female. Thomas (1931) presumably working with coprophila, wrote that the life cycle from date of egg laying to date of fly emergence was 18 to 23 days at 63 to $70^{\circ} \mathrm{F}$ ( 17 to $21^{\circ} \mathrm{C}$ ). At lower temperatures, development time was longer. Both Hungerford (1916) and Thomas (1931) illustrated life history stages of B. coprophila and plant damage caused by it. In Florida, the Florida State Collection of Arthropods has a record of $B$. coprophila being a severe problem on Christmas cactus, Zygocactus truncatus Schum., at a research center in Apopka during August 1977. There also is a record of it damaging 50 percent of 1000 seedlings of longleaf pine, Pinus palustris, at Punta Gorda during February 1975. The collector, Charles W. Chellman, noted the larvae invaded the tap roots and fed also on lateral roots near the soil line.

\section{Management}

Sound crop culture denies fungus gnats the conditions necessary for development, reduces need for pesticides and promotes parasites. Fungus gnat problems may result from overwet conditions and diseased roots and should alert growers to poor culture. Potting media should be stored dry, and pots and production areas must be well drained. Fungus gnats can exist on soil fungi, algae under benches, and on damp mossy benches. Some growers apply hydrated lime to eliminate the fungal food source (Price 1997).

The best growers stress good water management, good root health and are prepared to use insecticides correctly when fungus gnats are not otherwise controlled. When such practices are followed, fungus gnats should not be a problem.

Most of the larvae are in the top inch of soil. Rogue out any old plants and rotting materials. Avoid overwatering plants, since fungus gnats require moist to very moist soil or substrate for development. Steffan (1966) reported that, in general, both commercial greenhouse firms and commercial mushroom growers, practicing good cultural techniques, sustain very few losses from direct sciarid injury. R.I. Sailer (personal communication, 1977) reported that for small scale activities, before reusing potting soil, he successfully prevented buildup of damping-off organisms and sciarid flies by means of a scalding hot water treatment. 
See the Insect Management Guide for Fungus

Gnats in Greenhouse Ornamentals for more information.

\section{Selected References}

Hungerford, H.B. 1916. Sciara maggots injurious to potted plants. J. Econ. Ent. 9: 538-549.

Johannsen, O.A. 1912. The Mycetophilidae of North America, Part IV. Maine Agric. Exp. Sta. Bull., 200: 57-146.

Kennedy, M.K. 1974. Survival and development of Bradysia impatiens (Diptera: Sciaridae) on fungal and nonfungal food sources. Ann. Ent. Soc. America 67: 745-749.

Osborne, L.S. (29 December 2000). Fungus Gnats. University of Florida. http://www.mrec.ifas.ufl.edu/lso/fungusgnats.ht m. (June 28, 2001).

Pettey, F.A. 1918. A revision of the genus Sciara of the family Mycetophilidae (Diptera). Ann. Ent. Soc. America 11: 319-343.

Price, J., D. Short and L. Osborne. (May 1997). Management of Fungus Gnats in Greenhouse Ornamentals. UF/ IFAS Insect Management Guide. http://edis.ifas.ufl.edu/IG125. (June 28, 2001).

Shaw, F.R. 1953. A review of some of the more important contributions to our knowledge of the systematic relationships of the Sciaridae (Diptera). Proc. Hawaiian Ent. Soc. 15: 25-32.

Steffan, W.A. 1966. A generic revision of the family Sciaridae (Diptera) of America north of Mexico. Univ. Calif. Publ. Ent. 44: 1-77.

Thomas, C.A. 1931. Mushroom insects: their biology and control. Pennsylvania State Coll. Agric. Exp. Sta. Bull., 270: 1-42.

Valley, K. 1975. Flies (Diptera) in greenhouses. Pennsylvania Dept. Agric., Bur. Plant Ind., Ent. Circ. No. 5, in Regulatory Hort. 1: 9-10.

Wilkinson, J.D., and D.M. Daugherty. 1970a. The biology and immature stages of Bradysia impatiens (Diptera: Sciaridae). Ann. Ent. Soc. America 63: 656-660.

Wilkinson, J.D., and D.M. Daugherty. 1970b. Comparative development of Bradysia impatiens (Diptera: Sciaridae) under constant and variable temperatures. Ann. Ent. Soc. America 63: 10791083. 